\title{
EDITORIAL CONJUNTURA GLOBAL, V. 7, N. 2 (2018)
}

A Revista Conjuntura Global, v.7, n.2, 2018, como tem feito nos últimos dois anos, traz 6 artigos oriundos de pesquisas e trabalhos de pós-graduação. Nesta edição, encontramos assuntos atuais e voltados às relações internacionais na prática, como: a construção, os processos de negociação e operações de paz, adaptação e realocação de refugiados, integração regional e política externa.

No primeiro bloco, concentramos os artigos sobre a construção e operações de paz. O primeiro artigo, intitulado "The heritage of European International Society in multidimensional peace operations: Liberia as a case study", de Matheus de Abreu Costa e Souza, analisa o papel das operações de paz da Organização das Nações Unidas (ONU) na consolidação do Estado pós-conflito e por meio de instituições que asseguram valores e entendimento como Sociedade Internacional. Em seguida, o artigo de Devlin Biezus "A Construção de Paz e a Paz Híbrida: uma perspectiva sobre o Afeganistão" discute os conceitos de construção da paz, aplicando-os ao contexto do Afeganistão após a invasão estadunidense e a remoção do grupo Talibã da condução política central.

No segundo bloco, estão ainda artigos sobre negociação da paz e voltados à sociedade civil. No artigo "Sobre o papel da sociedade civil organizada na luta pelo reconhecimento das liberdades fundamentais durante os processos de negociação da paz: lições da guerra civil na Serra Leoa e do Acordo de Paz de Lomé", Erick da Luz Scherf e Rodrigo Milindre Gonzalez, examinam a ação da sociedade civil organizada na luta pelo reconhecimento das liberdades fundamentais durante os processos de negociação da paz na Serra Leoa, bem como avaliam sua efetivação. Bruna Leal Barcelos e Aline de Oliveira trazem uma discussão sobre as políticas públicas e os programas sul-coreanos para recebimento dos refugiados oriundos da Coreia do Norte, no seu artigo "Refugiados norte-coreanos: Adaptação e realocação social na Coreia do Sul".

No terceiro e último bloco, a temática trata da relação política doméstica x política externa. No artigo "Integração sem sentido: Desafios da política brasileira para integração econômica e comercial", Felipe Bernardo Estre explora questões internas que poderiam explicar a dificuldade para maior engajamento brasileiro no processo de integração regional. Por último, João Miguel Villas-Bôas Barcellos no artigo "Política externa indiana para o século XXI: a construção da potência mundial?" está voltado à reflexão acerca da estratégia da política externa indiana para o século XXI, período marcado pelo processo de abertura moderada ao comércio global e a tentativa de integração do país à agenda dos grandes temas discutidos nas relações internacionais. 
Encerrada a apresentação dos artigos da edição, gostaríamos de nos despedir dos nossos leitores. Esta é a nossa última edição à frente da Revista Conjuntura Global. É uma grande satisfação poder ter sido parte desta equipe, de ter trabalhado para o crescimento da revista e poder enxergar, de fato, sua evolução. Ao longo deste caminho aprendemos muito, e formamos uma verdadeira família. Aproveitamos a oportunidade para expressar nossos agradecimentos: i) ao Prof. Alexsandro Eugenio Pereira, pela confiança em nós depositada; ii) a toda equipe da Conjuntura Global, pelo apoio e amizade durante este tempo que estivemos responsáveis pelo processo editorial; iii) aos autores, que optaram por publicar conosco suas contribuições à área; iv) aos nossos leitores, que trazem sentido a todo nosso trabalho! Desejamos à nova Editora Executiva, Thaíse Kemer, e à toda nova equipe, muito sucesso em sua gestão.

Glaucia Julião Bernardo Editora Executiva 